\title{
Break-even Analysis and Profitability of Aquaculture Practices in India
}

\author{
R. SATHIADHAS ${ }^{*}$, T. M. NAJMUDEEN ${ }^{1}$ and SANGEETHA PRATHAP ${ }^{1}$ \\ ${ }^{1}$ Central Marine Fisheries Research Institute, \\ P. B. No. 1603, Cochin-18, India
}

\begin{abstract}
Economics of different aquaculture practices in India were worked out on annual basis and the break-even analysis has been done to compute the price required at a given level of production to cover all costs. While the shrimp-oriented aquaculture industry in India recorded exceptional growth for the last three decades in spite of its high exposure to risk and uncertainties, the farming/culture of various other species has not picked up to the expected level enabling the optimum use of potential areas suitable for aquaculture. The break-even price for the tiger shrimp through semi-intensive culture system is worked out at Rs.161/kg and Rs. 126/kg by improved extensive method, while it fetches market sales price of Rs. 350 to 400/kg. White shrimp culture is less risky and the break-even price worked out to Rs.166 / $\mathrm{kg}$ in semi-intensive and Rs. $88 / \mathrm{kg}$ in improved extensive culture while it obtains market sales price of Rs. 300-350/kg. Break-even price of other farming systems like crab culture worked out to Rs. 107/kg and crab fattening to Rs. $173 / \mathrm{kg}$ while the market sales price of crab is Rs. $250 / \mathrm{kg}$. In mussel culture, break-even price worked out to Rs. $3.35 / \mathrm{kg}$ (market sales price Rs.8/kg) while that of seaweeds (Gracilaria edulis) worked out to Rs. 7328/tonne in dried form (market sales price of dried seaweed is Rs.6000/tonne). The net profit varies for different systems of aquaculture from Rs.49,060/ha for traditional paddy cum prawn filtration system, Rs. 11.15 lakh/ha for crab culture and Rs.14.99 lakh/ha for crab fattening, Rs. 23.94 lakh/ha for pearl culture, Rs.9.48 lakh/ha/ year to Rs.6.03 lakh/ha/year for longline mussel culture in Karnataka and Kerala, Rs 1.85 lakh/ ha for rack and ren culture of edible oysters in Kerala and Rs.0.58/ha for the rope culture of Gracilaria edulis. The paper concludes that there is ample scope and feasibility for developing an integrated approach in the aquaculture practices in India. Other development strategies suggested for promoting aquaculture include introduction of legal framework for regulating all the types of aquaculture, delineating effective marketing strategies and development of parallel marketing avenues especially in the domestic market.
\end{abstract}

\section{Introduction}

Aquaculture has emerged as one of the fastest growing food farming systems at global level with enormous potential for further development. Although India with a

\footnotetext{
* Corresponding Author.

Email : rsathiadhas_seettd@yahoo.com
} 
production of approximately 2.3 million tonnes per annum is the second largest aquaculture producer, its contribution is hardly $5 \%$ of the global production. However, the country is endowed with a long coastline of $8129 \mathrm{~km}, 1.2$ million hectares of potential brackish water area and 0.5 million sq.km of continental shelf with diverse ecosystems, offering vast scope for development and diversification of coastal aquaculture.

In India, the traditional system of coastal aquaculture is practised in approximately 50,000 hectares in the low lying brackishwater areas of West Bengal, Kerala, Karnataka, and Goa without disturbing the ecological equilibrium. Besides the brackish water area, the shallow coastal region upto a depth of 30 meters are suitable for sea farming of approximately 73 species of various marine organisms of potential drug/pharmaceutical importance including finfishes (food fishes and ornamental fishes), crustaceans, molluscs, seaweeds, and sea cucumber (Devaraj and Appukkuttan 2000).

Inspite of the availability of different technologies for diversified farming practices of various candidate species, the coastal aquaculture in India is dominated by shrimp culture and in this process hardly $13 \%$ of the potential area is currently utilized. The high demand and the consequent price appreciation of shrimps in the international market led to its growth of production. While the shrimp-oriented aquaculture industry in India recorded exceptional growth for the last three decades, the farming/culture of other suitable species in different localities has not picked up to the expected level to enable the optimum use of potential areas suitable for aquaculture. Rational use of aquatic resources by judicious application of sustainable and diversified farming practices can ensure food security, increased employment opportunities, enhanced foreign exchange earnings and socio-economic upliftment of coastal rural poor.

\section{Materials and Methods}

Both primary and secondary data have been collected and utilised for the present analysis. Economics of different culture systems were given on annual basis as the duration of different practices varies from four months to one year. While working out the economics, the total cost indicated was the sum of annual fixed cost and annual operating cost. Operating costs include all those costs, which are incurred only when the farms are under operation and fixed costs are those incurred even if there is no culture operation. The fixed cost includes the interest on initial investment, depreciation of the permanent assets and insurance premium. The information collected from various publications has been updated by substituting the current input and output prices (2006-07). Similarly, the average yield and earnings per hectare for all type of aquaculture systems has also been worked out or projected irrespective of existing/optimum size of farms advisable and presented only to enable easy assessment of comparative efficiency. 
Break-even analysis has been used to assess the economic feasibility of the culture systems along with other indicators like net profit generated, annual fixed cost, and annual operating cost . The rate of return for each culture practice was calculated using the formula

$\mathrm{RR}(\%)=[(\mathrm{NR}+\mathrm{R}) / \mathrm{Ci}] \times 100$,

where NR is the net profit, $\mathrm{Ci}$ is the capital investment and $\mathrm{R}$ is the rate of interest on capital investment.

The break-even point is the point at which revenue is exactly equal to costs and hence no profit is made and no losses are incurred. The selling price, fixed costs or operating costs will not remain constant resulting in a change in the breakeven. Hence, these should be calculated on a regular basis to reflect changes in costs and prices and in order to maintain profitability.

The break-even production was calculated using the formula $\mathrm{BP}=\mathrm{TFC} /$ (Average farm-gate price per unit- Average variable cost per unit) Where BP is the break-even production and TFC is the total fixed cost.

\section{Results and Discussion}

\section{Shrimp culture}

The level of production of any commodity is determined by their price realization through market mechanism. Coastal aquaculture in India is also not an exception to this. High demand and unit value realization of shrimps, especially cultured shrimps in the export market has led to the increase in the production of penaeid shrimps through aquaculture. The proliferation of shrimp farming activity, in particular with the advent high input systems, helped in increasing the per capita yield and consequent economic returns to the farmers.

The economics of various shrimp farming systems in India have been worked out at different locations of the country (Jayagopal and Sathiadhas 1993; Usha Rani et al. 1993; Panikkar et al. 1995; Jayaraman et al. 1996; MPEDA 1998; Prasad 1999). In the present analysis, the key economic indicators such as rate of return and break-even price were calculated for all types of shrimp farming systems existing in the country. The indicative economics of semi-intensive farming of both the tiger shrimp Penaeus monodon and the white shrimp Fenneropenaeus indicus are given in Table 1. The data clearly shows that the annual net profit obtained from the farming of tiger shrimp is better than that of white shrimp. The break-even price for the tiger shrimp through 
semi-intensive culture system is Rs.161/kg whereas that of the white shrimp is Rs. $166 / \mathrm{kg}$. But the risk factor is lesser in $F$. indicus culture due to the robust nature of the species than that of $P$. monodon. There is not much difference in the capital investment and infrastructure facilities for the culture of both the species. The annual net profit for tiger shrimp culture is worked out at Rs.8.36 lakh/ha with a rate of return of $98 \%$, whereas the net profit for white shrimp culture is worked out at Rs.4.43 lakh/ha/year with a rate of return of $66 \%$ to the capital investment.

Table 1. Break-even analysis of shrimp culture systems in India (2006-07)

\begin{tabular}{lllllll}
\hline \multirow{2}{*}{$\begin{array}{l}\text { Type of farming system } \\
\text { Species cultured }\end{array}$} & & \multicolumn{2}{l}{ Semi intensive } & \multicolumn{2}{l}{ Improved extensive } & Extensive \\
\cline { 2 - 7 } & & $\begin{array}{l}\text { Tiger } \\
\text { shrimp }\end{array}$ & $\begin{array}{l}\text { White } \\
\text { shrimp }\end{array}$ & $\begin{array}{l}\text { Tiger s } \\
\text { shrimp }\end{array}$ & $\begin{array}{l}\text { White } \\
\text { shrimp }\end{array}$ & $\begin{array}{l}\text { Tiger } \\
\text { shrimp }\end{array}$ \\
\hline Annual fixed cost & (Rs. lakh) & 1.94 & 1.58 & 0.772 & 0.574 & 0.227 \\
Annual operating cost & (Rs. lakh) & 7.70 & 7.24 & 2.12 & 0.882 & 1.37 \\
Total costs & (Rs. Lakh) & 9.64 & 8.82 & 2.892 & 1.456 & 1.597 \\
Annual production & (Kg) & 6000 & 5300 & 2400 & 2000 & 2324 \\
Farm gate price & (Rs.) & 350 & 300 & 400 & 350 & 150 \\
Annual net operating & & & & & & \\
profit & (Rs. Lakh/ha) & 10.30 & 6.01 & 6.28 & 5.12 & 2.12 \\
Annual net Profit & (Rs. lakh) & 8.36 & 4.43 & 5.508 & 4.236 & 1.892 \\
Break-even production & (Kg) & 875 & 967 & 248 & 188 & 250 \\
Break-even price & (Rs./Kg) & 161 & 166 & 126 & 88 & 69 \\
Rate of return & (\%) & 98 & 66 & 165 & 169 & 150 \\
Input output ratio & & 1.87 & 1.50 & 2.91 & 3.40 & 2.19 \\
\hline
\end{tabular}

Very high profit levels from the improved extensive culture of Penaeus monodon and Fenneropenaeus indicus in Tamil Nadu were recorded. The annual net profit worked out at the present level for P. monodon is Rs.5.51 lakh/ha and that for $F$. indicus is Rs.4.24 lakh/ha. The break-even price for shrimps cultured by improved extensive method is lesser than that by the semi-intensive method. It is Rs.121/kg and Rs. $88 / \mathrm{kg}$ for $P$. monodon and $F$. indicus, respectively. The farm gate price is also lesser for $F$. indicus (Rs. 300/kg) compared to that of P. monodon (Rs.350/kg) and this makes the difference in their rate of return by $4 \%$.

The capital investment, as well as, the operating costs are also lesser in the improved extensive system of production compared to semi-intensive shrimp farming. An economic analysis of extensive shrimp farming for P. monodon in Andhra Pradesh has shown that the break-even price (Rs.69/kg) is still lesser than that of improved 
extensive farming. But the net profit is comparatively low with Rs.1.89 lakh/ha/ annum with a rate of return of $150 \%$ to the capital investment. In this culture system also, the major component of the operating costs is the feed cost (61\%) followed by salaries and wages $(12 \%)$. The factor-product relationship in prawn farming has been analysed by Kumar and Panikkar (1993) and they found that the level of production could be increased by using more efficient feed and better feed management.

\section{Integration of paddy and shrimp farming}

Integrated farming is the best means of increasing productivity from a unit area of land or water body. Integrated farming with crop, livestock and finfish or shellfish has been found to be a rewarding offer, helping to augment production of highly valued fish with minimum level of inputs. This is made possible by way of recycling of wastes/byproducts of one crop as input for the production of another.

In India, integrated farming is done in the Bheries of West Bengal, the Pokkali fields of Kerala, the Khazen lands of Goa and the Khar lands of coastal Karnataka, where during the rainy season, saline resistant traditional varieties of rice are grown. After the harvest of paddy, during the summer months, shrimp seeds along with other finfish seeds entering the fields with tidal water, are entrapped, grown for a period and harvested. In Kerala, during this period, a special variety of paddy called 'Pokkali', which is tolerant to 6-8 ppt salinity, is grown in these fields. Different species of shrimps together with fishes such as Mugil spp. Chanos chanos, Etroplus suratensis, Megalops cyprinoides, Lates calcarifer and Oreochromis mossambicus enter into the fields with the inflow of tidal water. The shrimp is the dominant one, but in most of the areas it is the commercially least important species like Metapenaeus dobsoni and M. monoceros, which dominates in comparison to the commercially important species like Fenneropenaeus indicus and Penaeus mondon. Regular thinning of crop by filtration is carried out in every new moon and full moon period. Final harvesting will be done at the end of the season by operating sluice net and cast net. The prawn yield from the traditional practice usually varies between $500-1000 \mathrm{~kg} / \mathrm{ha}$ depending upon the location of the field in relation to the bar-mouth, the distance from main water body, the size of the feeder canal, and the position of the sluice (Sathiadhas et al. 2000). In Kerala, out of 65,000 ha of brackish water area, more than 13,000 ha is under the traditional paddy cum prawn filtration system. 
Table 2. Economics of traditional system of prawn culture in pokkali field at Vypeen, Kerala (2006-07)

\begin{tabular}{llc}
\hline Economic Indicators & & Amount/Production \\
\hline Operating costs & (Rs.) & 14,840 \\
Average Annual Production & (kg/ha) & 736 \\
Gross Revenue & (Rs.) & 63,900 \\
Net profit & (Rs.) & 49,060 \\
\hline
\end{tabular}

Economic analysis of a paddy cum prawn culture system in Kerala showed that with a shrimp production of 700-800 kg/ha, a net profit of Rs.49,060/ha/crop is obtained from prawn filtration per hectare after 4-5 months. George (1980) worked out a production of $11,754 \mathrm{~kg}$ from a 16 ha filtration farm while Sathiadhas et al. (1989) worked out a production of only $8,590 \mathrm{~kg}$ from 17.11 ha filtration farm at Vypeen. The capital investment required is the cost of land and most of the farmers conduct this culture operation in leased lands which are normally having an area of more than five hectares. Rotation of prawn filtration with paddy is found to be the most eco-friendly farming system in this region. The total annual net profit from prawn culture works out at Rs.49,060/ha (Table 2).

\section{Crab culture/fattening}

In India, crabs used for domestic consumption, as well as, for exports are largely obtained from capture fisheries. The demand for live crabs in foreign market has prompted India to make efforts in large scale growing of mud crabs in confinements. Mud crab farming is picking up in recent years in states like Andhra Pradesh, Tamil Nadu and Kerala. The only constraint is the nonavailability of enough stocking materials for culture and fattening. It is therefore imperative that concerted efforts are needed to develop commercial hatchery for adequate and sustained supply of baby crabs to make mud crab farming an organized industry.

Sathiadhas and Najmudeen (2004) reviewed the economic efficiency of mudcrab farming/fattening under different production systems and evaluated its techno-economic performance by comparing them with semi-intensive shrimp farming. Net annual profit from the fattening system is Rs.14.99 lakh/ha and that of culture is only Rs.11.15 lakh/ha (Table 3). Annual profit from crab fattening with composite culture with fish and shrimp is approximately Rs.8.17 lakh/ha. Fattening system provides the highest rate of return of $244 \%$ followed by culture system (189\%), which is much higher than that obtained for all types of shrimp farming. Crab fattening with composite culture provides a rate of return of $145 \%$. 
Table 3. Break-even analysis of mud crab culture, fattening and crab fattening with composite shrimp/fish culture systems in Kerala, India (2006-07).

\begin{tabular}{|c|c|c|c|c|}
\hline Particulars & & $\begin{array}{c}\text { Crab } \\
\text { culture }\end{array}$ & $\begin{array}{c}\text { Crab } \\
\text { fattening }\end{array}$ & $\begin{array}{l}\text { Crab fattening } \\
\text { \&Composite fish } \\
\text { prawn farming }\end{array}$ \\
\hline Annual fixed cost & (Rs. lakh/ha) & 1.50 & 1.50 & 1.40 \\
\hline Annual operating cost & (Rs. lakh/ha) & 5.25 & 24.09 & 12.77 \\
\hline Total costs & (Rs. lakh/ha) & 6.75 & 25.59 & 14.17 \\
\hline Annual production & (kg/ha/year) & & & \\
\hline Crabs & & 3,150 & 12,715 & 8,000 \\
\hline Prawns & & & & 2,125 \\
\hline Fishes & & & & 1,958 \\
\hline Annual Revenue & (Rs.lakh/ha/year) & & & \\
\hline Crabs & & 17.90 & 40.58 & 20.00 \\
\hline Prawns & & & & 1.45 \\
\hline Fishes & & & & 0.89 \\
\hline Annual net operating profit & (Rs. Lakh/ha) & 12.65 & 16.49 & 9.57 \\
\hline Annual net profit & (Rs. lakh/ha/year) & 11.15 & 14.99 & 8.17 \\
\hline Break-even Price & $(\mathrm{Rs} / \mathrm{kg})$ & 107 & 173 & - \\
\hline Break-even production & $(\mathrm{kg})$ & 1125 & 1357 & 1549 \\
\hline Rate of return & $(\%)$ & 189 & 244 & 145 \\
\hline Input output ratio & & 2.65 & 1.59 & 1.58 \\
\hline
\end{tabular}

Even though the net profit and other indicators are higher in fattening system, the break-even price of crabs is higher (Rs.173/kg) compared to the culture system (Rs.107/kg). The economic analysis conducted in other places of the country also indicates its higher profitability as compared to other forms of aquaculture (Kathiravel et al. 1997; Anil and Suseelan 2001). Major reason for enhanced economic efficiency of crab culture and fattening is that it can be done with minimal initial requirements.

\section{Molluscan farming}

The major molluscan species suitable for coastal mariculture with high growth rate in India are mussels, oysters, clams and pearl oysters. At global level, molluscs contribute $18 \%$ to the total aquaculture production. If appropriate economical and sustainable culture technologies are applied, all these bivalves could be produced in large scale with much profit. Groups of farmers in the coastal area with the technology developed by the Central Marine Fisheries Research Institute (CMFRI) have taken up 
the mussel culture as a small scale farming activity with good profit. The Institute has also developed appropriate technology for edible oyster culture (Crassostrea madrasensis) in brackishwater areas and was found successful for commercialization. Another major technological achievement in bivalve mariculture has been the indigenously developed method for the culture and production of pearl, from the pearl oyster, Pinctada fucata. Recent attempt to culture pearl oysters in onshore tanks by the Institute has also proved to be successful.

\section{Pearl culture}

Pearls were considered to be the first precious gem known to mankind. India is endowed with the natural resources of the pearl oyster in the Gulf of Mannar and the Gulf of Kutch. The major pearl producing oysters in India are Pinctada fucata distributed in the Gulf of Mannar and Gulf of Kutch and the blacklip pearl oyster P. margaretifera in the Andaman and Nicobar Islands.

The pearls are classified into A, B, and C grades according to their quality, uniformity of coating and shape. The A grade pearls are sold at the rate of Rs.1500/g, B grade Rs.1000/g and C grade Rs.500/g. Even though India had the distinction of producing cultured pearls in 1973 itself, it could not produce cultured pearls for world trade. Pearl culture is a long-term investment and huge profits can be made in a successful culture operation, as there is great demand for pearls.

The economics of pearl culture differ between the culture methods and regions. The estimated production from a $6 \times 6 \mathrm{~m}$ floating raft culture is 1849 pearls/crop (Velayudhan 1995). Economic analysis of onshore pearl culture has been carried out at Visakhapatnam (Rao and Devaraj 1996; Rao 2005) and that of shallow water cage culture has been worked out at Vizhinjam, Kerala (Achari et al. 1998). The projected annual net profit from the open sea raft culture is very high against huge investments in the tune of Rs.67.40 lakh/ha. The break-even price for the pearls produced through open sea raft culture is worked out at Rs.33/pearl, if the culture is expanded to one hectare area (Table 4). For the present economic analysis, production rate from shallow bottom cage culture is estimated at about 1350,000 pearls/ha @ 700 pearls/cage, with a breakeven price of Rs.29/pearl. Achari et al. (1998) estimated a production of 1000 pearls/ cage of $65 \times 64 \times 64 \mathrm{~cm}^{2}$ size and this estimate is much higher than that of the other two culture systems. 
Table 4. Break-even analysis of pearl oyster culture systems in India

\begin{tabular}{llccc}
\hline Economic Indicators & & $\begin{array}{c}\text { Open sea } \\
\text { raft culture }\end{array}$ & $\begin{array}{c}\text { Shallow } \\
\text { bottom cage } \\
\text { culture }\end{array}$ & $\begin{array}{c}\text { Onshore } \\
\text { marine } \\
\text { culture }\end{array}$ \\
\hline Annual fixed cost & (Rs. lakh) & 37.85 & 8.55 & 8.98 \\
Annual operating cost & (Rs. lakh) & 76.79 & 378.99 & 18.00 \\
Total costs & (Rs. lakh) & 114.64 & 387.54 & 26.98 \\
Average annual production & (No. of pearls) & $3,50,000$ & 1350000 & 100000 \\
Break-even price & (Rs./pearl) & 33 & 29 & 27 \\
\hline
\end{tabular}

The break-even price of pearls from onshore pearl culture worked out at Visakhapatnam is Rs.27/pearl with a production of 1,00,000 pearls/ha. In all the three culture methods, the cost of labour is the major operating expenditure. Normally in the case of marine pearls, the pearls are sold on the basis of their weight rather than on the basis of numbers. Estimates on the production of pearls on weight basis are required to work out the real profit from all the above mentioned culture systems. Rao (2005) has estimated an annual pearl production of 27,000 $\mathrm{g} / 4000 \mathrm{~m}^{2}$ from onshore tank culture of pearl oysters at Visakhapatnam with a net profit of 23.94 lakh $^{-1} \cdot \mathrm{ha}^{-1}$.year-1 considering the culture period as 24 months. The economics of all the pearl culture systems worked out here are based on the experimental results and estimations obtained by research institutions of the country. In the case of open sea mariculture practices there are legal and other issues involved which may lead to higher cost of production than that of the projected figures.

\section{Mussel culture}

Culture of mussels gives the highest production rate among the edible molluscs. In India, two species of marine mussels (Green mussel Perna viridis and the Brown mussel Perna indica) are distributed in the rocky coastal areas where they support traditional sustenance fishery. Mussel culture was mainly done by raft method and long line method. As mussels are a relatively low priced product, export of mussel product from India is relatively a recent enterprise and the quantities are not substantial. Besides generation of alternative employment to fishermen, entrepreneurs can earn substantial profit by adopting mussel farming technologies. Diversification of products i.e. value added products may help in further spreading of mussel farming and its successful adoption.

With a culture duration of five to six months, two crops can be harvested in a 
year from the longline method. The estimated production of mussels from one meter rope is $10-12.5 \mathrm{~kg} / \mathrm{crop}$. From a longline unit of $360 \mathrm{~m}^{2}$ a total production of $54,720 \mathrm{~kg}$ shell-on mussels can be obtained, of which $40 \%$ will be the meat (Kuriakose and Appukkuttan 1996). Economics of the longline mussel culture has been worked out at Byndoor, Karnataka (Mohamed et al. 1998) and in Kerala (Velayudhan et al. 1998) by the Central Marine Fisheries Research Institute (CMFRI). The projected economics per hectare in the present analysis shows that the break-even price is higher in Kerala (Rs.4.8/kg) than that of Karnataka (Rs.3.35/kg). The cost of production in Kerala is high mainly due to high cost of labour and seed. An annual net profit of Rs.9.48 lakh/ha can be obtained from culture at Byndoor, whereas the net profit worked out in Kerala is approximately Rs.6.03 lakh/ha/year (Table 5).

Table 5. Break-even analysis of long line mussel culture systems in India

\begin{tabular}{llcc}
\hline Economic Indicators & & Karnataka & Kerala \\
\hline Annual fixed cost & (Rs. lakh) & 4.03 & 1.87 \\
Annual operating cost & (Rs. lakh) & 15.02 & 11.42 \\
Total costs & (Rs. lakh) & 19.05 & 13.29 \\
Average annual production & (tonnes) & 360 & 276 \\
Sale price & (Rs./Kg shell on) & 8 & 7 \\
Annual net profit & (Rs. Lakh) & 9.48 & 6.03 \\
Break-even production & (Tonnes) & 105 & 65 \\
Break-even price & (Rs./Kg) & 3.35 & 4.80 \\
Rate of return & $(\%)$ & 141 & 163 \\
\hline
\end{tabular}

\section{Edible oyster farming}

The edible oysters are widely distributed along the Indian coast. Of the six species of oysters belonging to the family Ostriedae, Crassostrea madrasensis is the dominant, having a wide distribution in the major backwaters in shallow coastal regions of India. Apart from the edibility of the meat, the shells have various industrial and agricultural uses. The indicative economics of the rack and ren culture of edible oysters in Kerala worked out by CMFRI in $300 \mathrm{~m}^{2}$ area and the projected economics per hectare area are shown in Table 6. An annual net profit of Rs. 1.83 lakh/ha can be obtained from the rack and ren culture with a capital investment of only Rs.3.05 lakh/ha. The rate of return worked out for culture in one hectare area is $72 \%$. 
Table 6. Break-even analysis of edible oyster culture by rack and ren method carried out in the backwaters of Kerala.

\begin{tabular}{llc}
\hline Economic Indicators & & Amount/production \\
\hline Annual fixed cost & (Rs. lakh) & 1.60 \\
Annual operating cost & (Rs. lakh) & 3.10 \\
Total costs & (Rs. lakh) & 4.70 \\
Average annual production & $(\mathrm{kg})$ & 10,200 \\
Farm gate price of heat shucked meat & (Rs/kg. $)$ & 60 \\
Net profit & (Rs. lakh) & 1.85 \\
Break-even production (heat shucked meat) & (kg) & 5404 \\
Break-even price for oyster with shell & $($ Rs./tonne) & 3686 \\
Break-even price for heat shucked meat & (Rs/kg) & 46.10 \\
Rate of Return & $(\%)$ & 72 \\
\hline
\end{tabular}

\section{Seaweed culture}

There is a very good demand for certain seaweeds in foreign countries, which are now under-exploited or unexploited in our country. Hence, they may be exploited and exported to earn foreign exchange to the nation. The bays and creeks present in the open shore along the east and west coast, lagoons and corals of the southwest coast of Tamil Nadu, Andaman Nicobar Islands and Atolls of Lakshwadeep have immense potential for cultivation of seaweeds, where commercial culture could be undertaken by the seaweed utilisers and the entrepreneurs. Since 1972, the CMFRI has been engaged in the cultivation of several economically important seaweeds and the method of cultivation of Gracilaria edulis, a fast growing species with minimum seed material has been standardized (Chennubhotla and Kaliaperumal 1998).

The economic analysis of the rope culture of $G$. edulis along the coast of peninsular India indicates that an annual profit of Rs.58,000/ha/year can be obtained from 4 successive crops with an operating cost of Rs.1,52,000/ha/year (Table 7). The breakeven price was worked out at Rs.7,238/tonne of dry seaweed. While in Minicoy Lagoon, the input requirement is less and the production rate is high and the net profit is also higher than which worked out for the culture along the Peninsular Indian coast (Chennubhotla 1996). 
Table 7. Break-even analysis of culture of seaweed Gracilaria edulis at Mandapam, Tamil Nadu.

\begin{tabular}{llc}
\hline Economic Indicators & & Amount/production \\
\hline Annual operating cost & (Rs. lakh) & 1.52 \\
Average annual production & (Tonnes) & 21 \\
Sale price of dry G. edulis & (Rs./tonne) & 10,000 \\
Annual net profit from 4 crops & (Rs. lakh) & 0.58 \\
Break-even price for wet seaweed & (Rs./tonne) & 1,810 \\
Break-even price for dry seaweed & (Rs/tonne) & 7,238 \\
\hline
\end{tabular}

\section{Conclusion}

The techno-economic evaluation of various aquaculture/mariculture practices reveals that there is ample scope for their product diversification rather than confining only to shrimp farming. The issues such as excess stocking rates beyond the carrying capacity, disease outbreaks and the possible environmental impacts in the fast pace of the development of shrimp farms necessitate the adoption of alternatives such as crabs and finfishes for brackishwater culture. The increasing export demand of crabs coupled with high price in the international market has stimulated the crab culture and fattening especially, in the states of Kerala and Tamil Nadu. The projected economics of open sea and onshore pearl culture practices should be further tested by transferring the technical know-how to the private farms for the commercial production. There is still great demand for pearls in the export market, which fetches the highest unit value. In addition, the feasibility of integrated shrimp culture with bivalves and finfishes are to be worked out and propagated to obtain maximum output through an eco-friendly system of farming. The concept of "Fishery estates" in the potential regions of this country with the introduction of diversified and integrated shrimp/finfish culture systems side by side should be promoted to accelerate the development of aquaculture industry. Special promotion incentives along with legal rights should be offered to the investors in these fishery estates to promote open sea mariculture.

There is need for introduction of legal framework for regulating all the types of aquaculture. The socio-economic acceptability of the inhabitants of the region also has to be taken into consideration before initiating such programmes. Promotion of ecofriendly coastal aquaculture is vital for generating employment and higher income for coastal fishermen. It is imperative to create proper marketing strategy for export marketing of aquaculture products in view of increasing aquaculture production and create parallel marketing avenues, especially in the domestic markets. Transformative 
changes were brought about in the attitude of the fishermen through extension. The transfer of technology efforts has helped to mitigate rural poverty by empowering the resource poor fishermen with access to technology and through employment generation activity and skill upgradation. Success achieved by the participating farmers has formed a model for others to start trying these technologies in their ponds that can contribute to social equity and environmental sustainability.

\section{Acknowledgements}

The authors thank Prof. (Dr). Mohan Joseph Modayil, Director, CMFRI, Kochi, for his constant encouragements and support for the preparation of this manuscript.

\section{References}

Anil, M.K. and C. Suseelan, 2001. Experimental fattening of the Green mud crab Scylla oceanica (Dana). In: Perspectives in Mariculture (Ed. Menon, N.G. and Pillai, P.P). Papers presented in the symposium on

'Eco-friendly mariculture technology package- an update' at MRC of CMFRI, Mandapam, pp.95-110.

Chennubhotla, V.S.K. 1996. Seaweeds and their importance. In: Artificial reefs and seafarming technologies (Ed.

K.K. Rengarajan). Bulletin of Central Marine Fisheries Research Institute 48: 108-109.

Chennubhotla, V.S.K. and N.K. Kaliaperumal, 1998. Seaweeds and their importance. In: Proceedings of the workshop of National Aquaculture Week. Jan-Feb., 1997. Held at Vijayawada, Chennai, Mandapam Camp and Tuticorin. The Aquaculture Foundation of India. pp.54-57.

Devaraj, M. and K.K. Appukkuttan. 2000. Perspective on coastal aquaculture in India. In: Marine Fisheries Research and Management (Ed. Pillai, V.N. and N.G. Menon), CMFRI, Cochin. pp 677-687.

George, K.V. 1980. Economics of Traditional prawn culture practices in Kerala with a note on the advantages of intensive prawn culture. Proceedings of the First International Symposium on prawn culture. 16-18 august

1978, Bombay. The Marine Products Exports Development Authority, Cochin. pp.131-137.

Jayagopal, P. and R.Sathiadhas. 1993. Productivity and profitability of prawn farming practices- an economics analysis. CMFRI Special Publication 55: 16-25.

Jayaraman, R., K. Karl Max and V. Sundara raj, 1996. Economics of improved extensive shrimp farming in Vedaranyam. In: Aquaculture for 2000 AD (Ed.Samuel Paulraj), Palani Paramount Publications, Palani. pp.55-58

Kathiravel, M., S. Srinivasagam, P.K. Ghosh and C.P. Balasubrahmaniam, 1997. Mud Crab Culture. CIBA Bulletin 10: 14 .

Kumar, A.V. and K.K.P. Panikkar, 1993. An analysis of factor-product relationship in prawn farming: a production function approach. CMFRI Special Publication 54: 85-93.

Kuriakose, P.S. and K.K. Appukuttan, 1996. Technology of mussel culture. In: Artificial reefs and seafarming technologies (Ed.K.K. Rengarajan). Bulletin of Central. Marine Fishery Research Institute 48: $70-75$.

Mohamed, S.K., C. Muthiah, D. Nagaraja and G. Sampathkumar, 1998. Initiation of marine mussel culture activities in Dakshina Kannada District, Karnataka. Marine Fisheries Information Service Technical and Extension Series 155: 10-15.

MPEDA, 1998. A Manual on Shrimp Farming. The Marine Products Exports Development Authority (MPEDA), Kochi, pp.171.

Panikkar, K.K.P., D.B.S. Sehara and R.Sathiadhas, 1995. Investment Avenues in Aquaculture Industry in Kerala. Fishing Chimes 29: 46-50.

Prasad, G. 1999. Growth and production of P. indicus in a low saline semi-intensive culture system of Kerala. Indian Journal of Fisheries 46(1): 25-31. 
Rao, G. S. 2005. Onshore (Land Based) Culture of pearl oysters for pearl production. Fishing Chimes 25(1):142-146.

Rao, G.S. and M. Devaraj, 1996. Prospects of large scale onshore marine pearl culture along Indian coasts. Marine Fisheries Information Service Technical and Extension Series 156: 1-7.

Sathiadhas, R. and T.M. Najmudeen, 2004. Economic Evaluation of Mudcrab farming under different Production

Systems in India. Aquaculture Economics and Management 8 (1/2): 99-110.

Sathiadhas, R., K.K.P. Panikkar, U.K. Satyavan and T. Jacob. 1989. Economic Evaluation of Paddy-Prawn Integrated Farming in Kerala. Seafood Export Journal 21(11): 9-21.

Sathiadhas, R., D.B. Sehara, K.K.P. Panikkar and R. Narayana Kumar. 2000. Economics of different production technologies. In: Marine Fisheries Research and Management (Ed. Pillai, V.N. and N.G. Menon), CMFRI, Cochin. pp 677-687.

Usha Rani, G. T. Chandra Reddy and K. Ravindranath. 1993. Economics of Brackishwater prawn farming in Nellore District of Andhra Pradesh state of India. Journal of Aquaculture in the Tropics 8: 221-230.

Velayudhan, T.S. 1995. Marine Pearl Culture. Technology Transfer Seires-5 (Ed. Srinath, K and R. Reghu), CMFRI, Cochin, pp.8.

Velayudhan, T.S., V.Kripa and K.K. Appukuttan, 1998. Production and economics of Edible oyster cultured in an estuarine system of Kerala. Marine Fisheries Information Service Technical and Extension Series

154: $1-6$. 